\title{
Art at School-Is There Any Perspective?
}

\author{
Cristiana Lopes Machado1, Tania Stoltz ${ }^{2}$ \\ ${ }^{1}$ Federal University of Paraná, Curitiba, Brazil \\ ${ }^{2}$ The Department of Education, Federal University of Paraná, Curitiba, Brazil \\ Email: cris.lm18@gmail.com
}

How to cite this paper: Machado, C. L., \& Stoltz, T. (2016). Art at School-Is There Any Perspective? Creative Education, 7, 2733-2747.

http://dx.doi.org/10.4236/ce.2016.718255

Received: September 20, 2016

Accepted: December 2, 2016

Published: December 5, 2016

Copyright (c) 2016 by authors and Scientific Research Publishing Inc. This work is licensed under the Creative Commons Attribution International License (CC BY 4.0).

http://creativecommons.org/licenses/by/4.0/

\begin{abstract}
Based on the premise that art is an important activity for human development (Vygotsky, 2001, 2009, 2010; Steiner, 2007, 2013), the aim of this study is to analyze the role of art in the everyday activities of schooling using conventional methods and also in schooling using alternative methods, the latter having been founded by $\mathrm{Ru}-$ dolf Steiner and referred to as Waldorf education. This study is justified by its making explicit the educational potential of art, whilst also seeking to contribute to the formation of teaching practices that consider the subject in a full manner. This is an exploratory qualitative study. Students and teachers from two elementary school classes of a municipal school in the State of Paraná were selected by convenience to take part in the study. Teachers and students from an elementary Waldorf reference school in the city of Curitiba were also selected. The participants were observed and the data were recorded in a field diary during one semester in each of the contexts. From the data collected it was possible to note that art is usually perceived as an element of leisure in schooling using conventional methods and its practice is based on mechanicalness. On the other hand, schooling using the alternative method uses art as a teaching tool, whereby the work of teaching is pervaded by the artistic element. This study brings indications of the need to review the importance given to art in traditional schooling, as well as to review practices that see art as an ally in the teaching process. As such, it would be fundamental for the Waldorf method to be better known, with the aim of contributing to the practice of teaching art in everyday schooling.
\end{abstract}

\section{Keywords}

Art, Education, Waldorf Education, Vygotsky, Steiner

\section{Introduction}

The purpose of this study is to analyze how art manifests itself in everyday schooling, 
with regard to the implications of the artistic and aesthetic element for the affective and cognitive development of the student. This study is justified in that it attempts to corroborate the educational potential of art and its contributions to the integral development of the subject.

Taking this into consideration, it can be seen that in order to achieve full development, affective, cognitive and social aspects should be equally involved in teaching methods, as indicated by Oliveira:

(...) in order to provide full development, schools need to take into account the cognitive, affective and social aspects of the student, as well as having as their aim the subject's autonomy, critical ability, and understanding of themselves as an agent capable of transforming reality. (Oliveira, 2010: p. 8)

Nevertheless, a variety of authors (Duarte-Júnior, 1995, 2010, 2012; Vieira \& Castanho, 2008; Camargo \& Bulgacov, 2008; Eça, 2010; Barbosa \& Pino-Juste, 2011; Ponce \& Saul, 2012; Sant'ana, Loos, \& Cebulski, 2013; Veiga \& Stoltz, 2014) agree that the current status of Brazilian education does not offer the possibility of integral development.

This fact, according to some authors (Duarte-Júnior, 1995, 2010; Vieira \& Castanho, 2008; Veiga \& Stoltz, 2014), is related to the ideological inheritance present in the establishment of curricula and teaching methods. According to Ponce \& Saul (2012), modernity has left as a legacy, the belief in reason as the only acceptable way of educating those who will be future citizens, whilst Camargo \& Bulgacov (2008) also consider that current times are guided by "calculating reason" which, driven by the aim of achieving economic benefits, only values quantitative characteristics in human and social relations. As such, these authors agree that everyday life has become guided by functionalism, practicality and by lack of sensitivity in relations between subjects in the majority of institutions. Given this, the belief in reason also transcends to everyday schooling. According to Ponce \& Saul (2012), the immediacy and practicality present as a premise in the contemporary world require education to:

(...) instrumentalize rapidly, technically offer reading abilities, undertake a brief journey through "ready-made" scientific and technological contents and, finally, provide a certificate. Economic criteria will be met, faith in reason will be maintained as an ideology and the frenetic need to change and produce results will also be satisfied (Ponce \& Saul, 2012: p. 8).

In view of this, the authors indicate that, by implication, this educational paradigm neglects the true quest of education which, according to them, is defined as preparing individuals capable of reading and understanding the world in its distinct forms; and this requires "full development of subjects and understanding of rationality as not being apart from emotions and ethical values which are instrumental and constitutive of existence" (Ponce \& Saul, 2012: p. 8). Saint'ana, Loos \& Cebulski corroborate with this by affirming that by separating affective, cognitive and moral aspects in human develop- 
ment, the current education system produces individuals who:

(...) grow up out of sync with their horizon of full development: cognitively advanced, towards sciences and the job markets, but without achieving the full potential of other existential dimensions present in everyday life, such as sensitivity in relation to the grandiosity of the beauty of things in the world and their social relations-which implicitly requires an adequate notion of ethics. (Sant'ana, Loos, \& Cebulski, 2013: p. 59)

As such, analyzing art in school education is essential for making evident the potential that it has for human development, with regard to its implications for the development of cognition, affectivity, sensitivity and morality. Adopting and valuing art and aesthetic experience in everyday schooling therefore becomes imperative in achieving the production of a sensitive, critical and autonomous subject, i.e. a subject that is truly human.

In view of this, this study intends to analyze art in everyday schooling in a public school using conventional methods and in a Waldorf school, the methods of which are pervaded with the artistic element (Stoltz \& Weger, 2012; Veiga \& Stoltz, 2014; Stoltz \& Weger, 2015; Andrade Silva, 2015; Stoltz, 2016), in the light of the aim of students achieving full development (Bach, 2007).

\section{Why Is Integration between Art and Education Essential?}

We live in society marked by inequality, given that we live in a paradox where many have little whilst few have a lot. According to Eça (2010), we live in a cycle of inequality, this is to say, in order for the cycle of social inequality to be maintained people must give up their decision-making power and transfer it to others. This in turn leads to "uncritical subordination" (Eça, 2010: p. 14).

In view of this the author indicates that in order to break this vicious cycle, i.e. the never-ending cycle of inequality in our society, value needs to be given to the role of education, as education is an important ally in the development of a culture of emancipation. As the author emphasizes:

(...) for them to become convinced of the importance of education, in both formal and non-formal contexts. Not an obsolete education fragmented in watertight disciplines, with pigeon-holed duration, in lobbies for certain areas of knowledge, in routine schools or one-off events held by cultural institutions. We need a new paradigm for education, concerted plans between places of learning, new forms of teaching, learning and evaluating which develop critical and independent thinking, imagination, sense of risk, curiosity for knowledge, facility of communication in all areas of expression and knowledge, taking into account individual and cultural diversities (Eça, 2010: p. 15, emphasis added).

It can therefore be seen that the need exists to review the current state of our education, as well as to refuse curricula and teaching methods with fragmented contents, pervaded by a large quantity of ill-considered contents. As such, Ponce \& Saul state that 
is "fundamental to revive the role of school education as well as the quest for a curriculum that encompasses human education in all its dimensions" (Ponce \& Saul, 2012: p. 8).

In this sense, according to Eça, art is necessary in curricula and teaching methods because of its potential to develop and enhance critical thinking. Following this perspective, several different authors (Camargo \& Bulgacov, 2008; Einser, 2008; Oliveira \& Telles, 2014) point to the need for art to be integrated in teaching, as an important factor for students to develop and enhance their perception of the reality surrounding them, as Camargo \& Bulgacov state:

(...) by getting closer to the arts, aesthetics can become an instrument for educating with regard to sensitivity, leading us to discover ways of perceiving the world thus far unknown. Through experiencing aesthetics people develop the capacity of sensitivity, perception, and build a vision which encourages them to perceive reality from diverse angles and its diverse aspects. (Camargo \& Bulgacov, 2008: p. 469, emphasis added)

Eisner (2008), in turn, postulates that when art is integrated into education it leads students to learn in a more qualitative manner, i.e. through integration between art and education students learn to look at everyday and social facts with questioning and creative eyes that search for possibilities and do not merely accept what is presented to them.

In essence, art and creative activities integrated into school education are stated to be important allies for social change, given that they enable students to change their views on reality. This integration therefore becomes imperative for ensuring a future with less inequality, as here we are postulating that art and education by themselves cannot save the world but nevertheless contribute to the development of more critical and autonomous subjects, aware of the inequalities and inconsistencies the world offers us.

\section{The Implications of Art for Human Development}

As mentioned above, art and aesthetics integrated into education are important for the development of a subject with broader perceptions, capable of looking at and perceiving the surrounding world from different perspectives and not just those imposed by predominating mass media. Art in education therefore becomes essential for student emancipation, which in turn can contribute towards social transformation. But how does art act on human development? How does it act in the process of people's affective and cognitive development?

Taken from the perspective of Vygotsky (2001), founder of cultural-historical psychology, art is a complex activity that should have the same weight as science (rationality) in the psychological organization of mankind. Thus, for Vygotsky, art is just as important as science for the psychological development of the subject. According to him "(...) poetry or art is a special way of thinking which, in the final analysis, leads to the same results as scientific knowledge" (Vygotsky, 2001: p. 34). In view of this, we can 
perceive that art goes beyond just providing subjects with entertainment. Art, according to the author, because it is a complex activity, involves the distinct aspects of human nature, that is to say, it is an activity that integrates both emotions and intellectuality. As such, Vygotsky indicates that art "is the work of the intellect and of very special emotional thinking" (Vygotsky, 2001: p. 57).

By integrating thought and emotions, art entails full and more qualitative development of students, given that emotions, from a Vygotskyan perspective, underlie all the subject's behaviours (Vygotsky, 2009). As the author emphasizes:

Emotional reactions exert the most substantial influence over all forms of our behaviour and moments of the educational process. We want students to achieve better memorization or more successful work of the intellect. In either case we must concern ourselves with ensuring that both these activities are stimulated emotionally (Vygotsky, 2009: p. 143).

With regard to how the aesthetic experience acts on mankind's psychological system, Vygotsky also indicates that there is no lack of psychic energy in aesthetic reactions, on the contrary, in their involvement with art subjects use all aspects of their psychological system. According to Vygotsky: "our aesthetic reaction reveals itself to us above all not as a reaction that saves, but rather as a reaction that destroys our nervous energy" (Vygotsky, 2001: p. 257). By discharging a lot of psychic energy, art, in turn, evokes all the individual's psychological capacities, as follows:

Art may provoke a new and more elaborate psychic organization, because of its being a cultural instrument, which aims to achieve, through its form and content, higher human strengths such as: abstraction, creativity, perception, emotion and imagination (Barroco \& Superti, 2014: p. 26).

In this sense, Eisner agrees with Vygotsky by postulating that art, through its images and properties, works as a mechanism that mobilizes psychic activities, since it provides opportunities for employing all the abilities of the human mind. According to Eisner, art provides:

(...) an ample contribution to human development and experiences. Firstly art, i.e. images and events as opportunities which cause aesthetic forms of feelings to burgeon, is one of the ways through which the potentialities of the human mind are brought out. Our intellectual capacities become intellectual skills to the extent that we give these capacities opportunities to work. (Einser, 2013, p. 126)

Also with regard to which implications the artistic and aesthetic elements provide for human development, Vygotsky $(2001,2009)$ indicates that art is a vital activity for mankind, given that for the author art goes beyond the mere contagion of feelings among those involved with it, and rather is characterized as an activity the aim of which is to achieve balance in mankind's relationship with the milieu. From Vygotsky's perspective, at times this relationship is balanced and at others it is unbalanced. Imbalance would be the accumulation of energy that finds no way of being released in everyday 
life and as such art would be an instrument that materializes unreleased yearnings, anguish and joys. As such in this author's opinion art enables the individual to remain psychologically healthy. In this respect, Vygotsky highlights that "art constitutes an imperishable and biologically essential mechanism by means of which excitations that have remained unrealized in life are discarded, and, in one form or another, is an entirely inevitable companion of every human existence" (Vygotsky, 2009: p. 338). He also postulates that: “(...) art is the highest concentration of all the biological and social processes in which the individual is involved in society, that is a mode of finding a balance between man and the world in the most critical and responsible moments of life" (Vygotsky, 2001: pp. 328-329).

As such we can perceive that art entails making possible opportunities for subjects to express themselves. Camargo \& Bulgacov (2008) stress that subjects need to express their feelings and thoughts, and that art is the appropriate means for satisfying this need, given that through art there is objectification of feelings.

With regard to the educational contributions of art, according to Vygotsky's cultural-historical theory (2009), art is like a driving force capable of assisting the child's development, since art can support learners in organizing their experiences and emotions in relation to their context. Vygotsky therefore emphasizes that:

a child's drawing is always an educationally gratifying event, though it is sometimes also aesthetically grotesque. It always teaches the child to master the aggregate of his own experiences, to conquer and transcend them, and, as one writer has expressed it rather elegantly, teaches the psyche how to ascend. (Vygotsky, 2009: p 346)

In view of this, as we behold the contributions that art brings for lives in development, a special examination needs to be made of how this element is used in our schools with the aim of attempting to enable the best development and learning for our students.

\section{Method}

This is a qualitative study using an exploratory approach and its aim is to identify how art is expressed in everyday schooling. The premise of the qualitative research approach is to analyze phenomena in their natural environment (Bogdan \& Biklen, 1994). By taking the natural environment as a source of data, the qualitative approach tends to examine all the nuances of the study context so as to obtain an overall view of it, whilst using the observer as a data collection instrument, as emphasized by Bogdan \& Biklen:

The qualitative research approach requires that the world be examined based on the idea that nothing is trivial, that everything has the potential to form a course that enables us to achieve a more enlightened understanding of our object of study. (Bogdan \& Biklen, 1994: p. 49)

This study was conducted in two stages. In the first stage the study context was a public school in a municipality in the metropolitan region of the city of Curitiba, Brazil. 
In the second stage the study took place in a school specializing in the Waldorf education method in the city of Curitiba.

At the municipal school where the first stage of the study was conducted, two $3^{\text {rd }}$ year elementary education classes were selected. Each class had distinct characteristics in that the teachers (female) in charge of each class used different teaching practices, thus enabling different practices to be observed within a school using conventional methods. One of the classes was comprised of 23 enrolled students whilst the other had 14 enrolled students. Average student age was between eight and ten years-old.

Data was collected by means of participant observation as this allows direct contact with the phenomena studied (Severino, 2007). According to Gil (2010), this enables the observer to participate in all aspects of the context that is being studied and this in turn enables more comprehensive data to be collected. All data collected were recorded in a field diary.

In the first stage of study, observation took place during the second semester of the 2014 school year. Observation occurred two days a week, these days being alternated as the study progressed so as to enable analysis of all the aspects of the contexts. This resulted in total of 18 data collection observations, all of which were recorded in a field diary.

In the second stage of the study, a $4^{\text {th }}$ year class at a school using the Waldorf method was selected by convenience. Here the study participants were the teacher in charge of the class and 14 enrolled students. Observation took place twice a week during the first semester of the 2015 school year, resulting in a total of 11 observations.

Data analysis was performed on the records contained in the field diaries. Initially these were read several times with the aim of creating an initial descriptive spreadsheet of the elements that most stood out in the classes in relation to the artistic and creative element in schooling practice. Following this, the spreadsheets themselves were read with the aim of identifying uniformities in the field diary records and how art and the artistic element are expressed in everyday schooling, thus creating categories.

\section{Results and Discussion}

Among the uniformities found in the field diaries regarding the first school analyzed (the municipal school), there are three categories relating to the manifestation of art in everyday schooling in a public school using conventional teaching methods. These elements translate how art appears in this context. The categories are: mechanicalness in everyday schooling, art as a recreation and artistic activities that promote learning.

The first category defined as mechanicalness in everyday schooling refers to teaching based on the mechanical reproduction of contents, so that little space is reserved for activities involving creation and subjective expression by the students. This category was found in both classes analyzed at the municipal school, as shown by the following examples:

The students sit in rows and copy the contents that teacher Célia writes on the blackboard. The activity written on the blackboard is entitled "measurements of 
time". The teacher copies the contents from her textbook and writes them on the blackboard. When she has finished writing the questions on the blackboard the teacher goes from desk to desk to see whether the students have made spelling mistakes. She also tells the students to find the answers in the handouts. After a while, teacher Célia begins to answer the questions with the students. She asks each student to answer a question. The students become anxious to answer the questions, and some even answer when it's their colleagues turn and are told off by the teacher. Depending on the answers, Célia writes them on the blackboard and the students have to check whether their answers are correct. Some students do not answer the questions on their own and just copy the answers from the blackboard. (Field Diary 13-11-2014)

After telling the students the story about "the King's new clothes", teacher Marli tells the students to do the activities contained in the textbook, these activities are questions and answers about the text she read. The students have to write the answers in the textbook. When they have finished the students read their answers out loud and correct them together with the teacher (Field Diary, 17-09-2014).

In this category it was possible to analyze that students do activities using photocopies, textbooks or by copying from the blackboard. They just have to answer them. As a rule images are provided in a finished format, which means that students do not have the opportunity to use their creativity. Even in activities which require students to create, the elements for this "creation" are already provided.

As a consequence it was observed that the atmosphere in the classroom when there are no creative activities, or when there is excessive reproduction of contents, is one of dispersion, very noisy and difficulty in assimilating the contents.

The second category, art as recreation, refers to how art usually appears in the context studied and how it is conceived of within this environment. In this category art appears as a form of student entertainment or recreation during breaks between activities considered to be "serious", as in the following examples:

After the teacher has explained how to do today's test, a student asks her if he can do a drawing after the test. The teacher replies that the student can draw whatever he wants as long as all his answers to the test are written correctly (Field Diary 25-11-2014).

After reading the story, the students answer interpretative questions on a sheet of paper handed out by the teacher. This activity contains illustrative drawings. Once they have finished answering the questions the students can colour the illustrations while they wait for the rest to finish the same task (Field Diary 24-09-14).

The third category, using the artistic element as a learning factor, was found in just one of the classes analyzed (teacher Marli's class) and refers to how art is used and what its implications for learning are. In the class analyzed the teacher was found to be constantly concerned about using different methods in her teaching practices. It was observed that this teacher sought to provide her students with creative moments and gen- 
erally used artistic activities interspersed between other contents. It could be seen that the students responded well to these investments and stimuli made by the teacher, as was observed in these examples:

The students perform a play for which they themselves have written the script. The play is an adaptation of the tale of John and Mary. One student acts as the narrator while the rest perform the adaptation of the tale. The students take part actively in this activity. All the students cooperated in producing the scenery and the outfits (Field Diary, 30-09-2014).

The teacher brings the students together in a circle and reads a story to them (Cinderella). When she finishes reading the students are asked to create an adaptation of the story. The students are invited to create and give their suggestions on how to adapt it. As the students suggest ideas, the teacher builds the text on the blackboard, taking care to ensure the students help to produce the text. The students demonstrate a lot of interest in this activity. They offer ideas and plan how they will perform the adaptation (Field Diary 01-10-2014).

Based on the records in the diaries kept at the school using the Waldorf method, it was possible to find three categories related to the expression of art in everyday schooling. These categories were: art as an instrument for affective development, art as a means of teaching and art as a means of expression.

The first category, defined as an instrument for affective development, refers to how art appears in the everyday activities of the class studied. Here art is used as an element that favours the student's emotional development, by using artifices such as songs and poems intended to enable students to examine their emotions and feelings, with the aim of helping them to cope with them. The teacher told the observer that at the beginning of the year each student receives a verse that they have to recite to the rest of the class. The verse is related to aspects of their emotional characteristics. The teacher explained that the verse is used as a therapeutic element for each student. The songs, which are sung by all the students in the class, have the same purpose, namely to put the class in harmony, as in the following example:

Every morning as soon as the students enter the classroom they recite the poem together. The entire class recites a poem giving thanks for the day, for nature. Following this, when told to do so by the teacher, each chosen student recites their verse to the rest of the class. This verse usually has something to do with the student's own characteristics (Field Diary, 13-04-2015).

The second category, defined as art as a means of teaching, is related to the way in which art appears every day in this class. Here art is used as an instrument for teaching the contents that are being studied. When studying a given subject, whether it was mathematics, geography, history or literature, art was present as a means of helping the student to learn. This involved the use of songs, poems, drawing or painting, dancing and role play linked to the subject being studied, as can be seen in the following examples: 
At the beginning of the lesson the students form a circle together with the teacher. First of all they make steps in rhythm and move in an anticlockwise direction. Gradually, as the melody of the music becomes established, the students receive indigenous musical instruments from the teacher and, when the teacher tells them to, each student plays their instrument. Following this, while they play the instruments, the students begin to sing the song entitled "música do Pajë, by Villa Lobos (Field Diary, 18-05-2015).

In today's lesson the students are learning about watercolour. At the beginning of the lesson the children look at the watercolours they painted in previous lessons. The teacher encourages the students to think about the feelings the watercolour provokes. Following this, the teacher says that the students will express in watercolour the feeling of "yearning for a new day", making a connection with the contents of literature studied by the students in earlier lessons (Field Diary, 28-052015).

The third category, defined as art as a means of expression and found by analyzing the diaries, refers to art as an element that favours expression and creation in everyday schooling activities. Here it can be seen that images are used as a way of helping students to express themselves regarding the subject that is being studied.

In today's lesson the subject is geography and the teacher is working with the students on geographic coordinates. At the end of the explanation about the neighbourhood where the school is located, the teacher asks the students, based on what has been explained, to reproduce in pictures the map of the neighbourhood and a compass rose (Field Diary, 13-04-2015).

In today's lesson the teacher "corrected" the activities that the students were to have done at home. Their task was to watch the sunset on the day before and, based on their feelings on what they observed, they had to create a text and an image of what that moment meant to them. Some students, in addition to producing texts, also created poems about the sunset and beautiful images of it. At the end, they all admire each other's creations (Field Diary, 04-05-2015).

The analysis of the data revealed that the public school observed which used conventional teaching methods, dedicates little space to art and creation in its everyday activities (as presented in category 1 and 2). This is due to the fact that to a large extent teaching methods remain entrenched in the ideal that it is only through the intellectual approach that the best learning can be achieved. Despite studies that demonstrate the contributions of art to human development (Duarte Jr., 1995, 2010, 2012; Barbosa \& Pino-Juste, 2011; Stoltz \& Weger, 2012; Schleder \& Stoltz, 2014; Veiga \& Stoltz, 2014; Stoltz \& Weger, 2015; Andrade Silva, 2015), art continues to be undervalued in the traditional educational context.

In the view of Pinheiro (2014), the fact that art still occupies little space in formal education is related to the dominant line of thinking which assumes that art belongs only to the better off classes. According to the author, this contributes to maintaining 
the cycle of inequalities in our society:

The discipline of arts is always the first to be cut to make way for stronger disciplines such as Portuguese and mathematics. The importance of these areas cannot be denied, but teaching arts at school is known to be at a disadvantage, the same as philosophy, sociology, as part of a dictatorial project to cut humanities and replace them with disciplines intended to disseminate dominant ideologies. (Pinheiro, 2014: p. 96)

Pinheiro also indicates that although schools are a favourable space for working with art and although the idea of art as a specific human activity is disseminated, regardless of social class, this is not what happens in our conventional schools, given that "the contemporary school has served as an instrument of hegemonic reproduction, within the dictates of neoliberal ideology" (Pinheiro, 2014: p. 96).

Nevertheless, the analyses of the data indicate that although schools do suffer these influences, there are still some professionals who seek to use alternative teaching practices (as was evident in teacher Marli's class). Despite this teacher seeking to use the artistic and creative element, as mentioned earlier, nonetheless the time dedicated to these activities at school can be perceived to be scarce. This is due to the point of view disseminated in our society that art is only for entertainment or for the wealthier classes (Magro, 2005; Bergonski \& Stoltz, 2014). This is in line with the opinion of Duarte Júnior, who states that: "art continues to be seen, inside school itself, merely as leisure, a form of amusement in-between the "useful" activities of the other disciplines" (Duarte-Júnior, 2012: p. 81).

In view of this it is evident that schools as they are at the moment need to reassess their priorities and seek teaching practices aimed at the emancipation of the subject as well as contributing to their development taking place in an integral manner. The analyses of the records in the diaries kept at the school using the Waldorf methodology make it evident that this teaching practice is contrary to the materialistic trend that pervades conventional education, given that it is based on the principle that a subject's education should occur in a complete manner whereby teaching practices are planned with the development of the child or adolescent in mind (Steiner, 2007, 2013; Veiga \& Stoltz, 2014; Andrade Silva, 2015; Stoltz, 2016). Thus, based on the uniformities found in the diaries, it was seen that the artistic element pervades all Waldorf teaching and is, therefore, an instrument used in the process of the student's development with regard to the affective, cognitive and volitional aspects.

As explained in the categories "art as a means of teaching" and "art as an instrument for affective development", all subjects at the Waldorf school are taught imbued with music, dancing, painting and poetry. This occurs because, for Steiner, the founder of Waldorf Education, the psychological mechanism takes place between "observing and thinking, between feeling and thinking, which, by its effect, motivates thought and individuality" (Schleder \& Stoltz, 2014: p. 110). In this context art becomes an important tool that seeks to regain all aspects of the subject, such as emotion, creativity, intellectuality and perception during the educational process (Stoltz \& Weger, 2012; Stoltz, 
2016). In this sense, Carlgren \& Klingborg (2006) stress that:

When the characteristic expression of an animal is reproduced in clay or wood, when painting or drawing an effort is made to achieve the maximum that the material can give to the work intended, when, between audacity and test of patience, one works to form an image, the involvement of the entire personality is experienced. (Carlgren \& Klingborg, 2006: p. 49)

With regard to the category "art as a means of expression" it can be seen that as a rule the students were provided with opportunities to create and express their feelings in relation to the contents studied. Through the element involving images, the students could combine both their feelings and their thoughts with the contents they studied. This is in keeping with the ideas of Duarte-Júnior (2012). For this author, learning is a dialectic between what we feel and what we think. Therefore, by taking on expression through art, children can vent their feelings and emotions (Carlgren \& Klingborg, 2006; Vygotsky, 2001, 2009). This results in children being able to acquire better self-knowledge and develop autonomous and critical reasoning about that which is presented to them, given that for Steiner "children need pictorial language to nurture their psychological universe which, in the future, will become the basis of transformation into thought and formation of judgements" (Bach \& Stoltz, 2014: p. 117).

\section{Conclusion}

The main objective of this study was to analyze how art is expressed in everyday schooling using either conventional methods or Waldorf methods in order to identify what implications the artistic and creative element have for student development.

Based on the analysis of the data collected in both contexts it could be seen that in the school using conventional methods little space is reserved for creation and involvement with artistic activities, given that its teaching practices continue to be embedded in mechanicalness and the reproduction of contents. As a result, it was observed that the atmosphere in the classroom becomes tiresome for students and there is little contribution to their development.

On the other hand, the study also found signs that there are teachers who strive to use alternative methods in their teaching practices. Notwithstanding, they encounter difficulties in working with art and creation within traditional everyday schooling. It can therefore be said that education professionals need to be better prepared to work with art in the school environment.

This preparation can begin at the teacher training stage, by providing future teachers with greater knowledge about alternative teaching methods, such as Waldorf Education, given that this study points to this form of education as showing itself to be feasible and having many contributions to offer to traditional education.

\section{References}

Andrade Silva, D. A. de. (2015). Educação e ludicidade: um diálogo com a Pedagogia Waldorf 
[Education and Ludicity: A Dialogue with the Waldorf Pedagogy]. Educar em Revista, 56, 101-113. https://doi.org/10.1590/0104-4060.41463

Bach, J. (2007). Educação ecológica por meio da estética na Pedagogia Waldorf [Ecological education through aesthetics in the Waldorf Pedagogy] (p. 230). Dissertação (Mestrado em Educação), Curitiba: Setor de Ciências Humanas, Educação e Artes, Universidade Federal do Paraná.

Bach, J., \& Stoltz, T. (2014). Educação, arte e linguagem em Steiner e Vygotsky. In T. Stoltz, \& M. Veiga (Eds.), O Pensamento de Rudolf Steiner no debate científico [The Thinking of Rudolf Steiner in the scientific debate] (pp. 113-132). Campinas: Alínea.

Barbosa, F. M. B., \& Pino-Juste, M. (2011). A estética como fator promotor da aprendizagem [The Aesthetics as a Promoter of Learning]. Teoria Educacion Salamanca, 23, 91-109.

Barroco, S. M. S., \& Superti, T. (2014). Vigotski e o estudo da psicologia da arte: contribuições para o desenvolvimento humano [Vygotsky and the Study of Psychology of Art: Contribution for de Human Development]. Psicologia e sociedade, 26, 22-31.

https://doi.org/10.1590/S0102-71822014000100004

Bergonski, S. S. S., \& Stoltz, T. (2014). Arte e sua relação com a vida: Para além do entretenimento. In T. Stoltz, \& M. Veiga (Eds.), O Pensamento de Rudolf Steiner no debate científico [The Thinking of Rudolf Steiner in the Scientific Debate] (pp. 133-164). Campinas: Alínea.

Bodgan, R., \& Biklen, S. (1994). Investigação qualitativa em educação: Uma introdução à teoria e aos métodos [Qualitative Research in Education: an Introduction to Theory and Methods]. Portugal: Porto Editora.

Camargo, D. \& Bulgacov, Y. L. M. (2008). A perspectiva estética e expressiva na escola: Articulando conceitos da psicologia sócio-histórica [The Aesthetic and Expressive Perspective in the School: Articulating Concepts of Socio-Historical Psychology]. Psicologia em estudo, 13, $467-$ 475. https://doi.org/10.1590/S1413-73722008000300007

Carlgren, F., \& Klingborg, A. (2006). Educação para a liberdade: a pedagogia de Rudolf Steiner [Education for Freedom: The Pedagogy of Rudolf Steiner]. São Paulo: Escola Waldorf Rudolf Steiner.

Duarte-Júnior, J. F. (1995). Fundamentos estéticos da educação [Aesthetic fundamentals of education] (4th ed.). Campinas: Papirus.

Duarte-Júnior, J. F. (2010). O sentido dos sentidos: a educação (do) sensível [The Meaning of the Senses: Sensitive Education] (5th ed.). Curitiba: Criar Edições UFPR.

Duarte-Júnior, J. F. (2012). Por que arte-educação? [Why Art-Education?] (22nd ed.). São Paulo: Papirus editora.

Eça, T. T. P. (2010). Educação através da arte para um futuro sustentável [Education through Art for a Sustainable Future]. Cadernos Cedes, Campinas, 30, 13-25. https://doi.org/10.1590/S0101-32622010000100002

Einser, E. (2008). O que pode a educação aprender das artes sobre a prática da educação? [What Can Education Learn from the Arts about the Practice of Education?] Curriculo sem fronteiras, Stanford, 8, 5-17. http://www.curriculosemfronteiras.org/vol8iss2articles/eisner.pdf

Einser, E. (2013). Estrutura e mágica no ensino da Arte. In A. M. Barbosa (Ed.), Arte-Educação: leitura no subsolo [Art-Education: Reading Underground]. São Paulo: Cortez.

Gil, A. C. (2010). Como elaborar projetos de pesquisa [How to Design Research Projects]. São Paulo: Atlas.

Magro, A. R. (2005). Arte educação: Necessidade ou superfuidade? [Art Education: Need or Superfine?] Colloquium Humanarum, 3, 23-26. 
Oliveira, M. C. S. L., \& Telles, J. M. (2014). Aliando experiência estética e o debate de ideias: implicações para as praticas educativas na escola. In M. A. Dessen, \& D. A. Maciel (Eds.), $A$ ciência do desenvolvimento humano: Desafios para a psicologia e a educação [The Science of Human Development: Challenges for Psychology and Education] (pp. 201-204). Curitiba: Juruá.

Oliveira, M. E. (2010). Teatro na escola e caminhos de desenvolvimento humano: Processos afetivo-cognitivos de adolescentes [Theater at the School and Ways of Human Development: Affective-Cognitive Processes of Adolescents]. (p. 263). Dissertação de [Mestrado em Educação], Curitiba: Setor de Educação, Universidade Federal do Paraná.

Pinheiro, M. L. (2014). A reflexão estética como ponto de partida para o entendimento da importância da arte na escola [The Aesthetic Reflection as a Starting Point for Understanding the Importance of Art in School]. EccoS Revista Científica, 35, 95-110.

http://www.redalyc.org/pdf/715/71535318006.pdf

Ponce, B. J., \& Saul, A. A. (2012). A necessidade da estética e da ética no currículo escolar do século XXI [The Need for Aesthetics and Ethics in the School Curriculum of the 21st Century]. Psicologia da Educação, 34, 6-19.

Sant'ana, H. L., Loos, R. S. S., \& Cebulski, M. C. (2013). A arte, a afetividade e o sistema educacional: O desenvolvimento humano em questão [Art, Affectivity and the Educational System: The Human Development in Question). Pensamento Educacional, 8, 55-72.

Schleder, K., \& Stoltz, T. (2014). Arte só para artistas? Considerações a partir de R. Steiner. In T. Stoltz, \& M. Veiga (Eds.), O pensamento de Rudolf Steiner no debate científico [The Thinking of Rudolf Steiner in the Scientific Debate] (pp. 91-112). Campinas: Alínea.

Severino, A. J. (2007). Metodologia do trabalho científico [Methodology of Scientific Work]. São Paulo: Cortez..

Steiner, R. (2007). A educação da criança segundo a ciência espiritual [The Education of the Child According to Spiritual Science]. São Paulo: Antroposófica.

Steiner, R. (2013). A arte de educar baseada na compreensão do ser humano [The Art of Educating Based on the Understanding of the Human Being]. São Paulo: Antroposófica, Federação das Escolas Waldorf no Brasil.

Stoltz, T. (2016). Imaginação e criatividade na escola: A necessidade de outro olhar. In Piske et al. (Eds.), Altas habilidades/superdotação (AH/SD) e criatividade: identificação e atendimento [Giftedness and Creativity: identification and specialized service] (pp. 191-206). Curitiba: Juruá.

Stoltz, T., \& Weger, U. (2012). Piaget and Steiner: Science and Art in the Process of Formation. Research on Steiner Education, 3, 134-145. http://www.rosejourn.com/index.php/rose/article/view/106/131

Stoltz, T., \& Weger, U. (2015). O pensar vivenciado na formação de professores [Experiential Thinking in Teacher Training]. Educar em Revista, 56, 67-83. http://www.scielo.br/scielo.php?script=sci arttext\&pid=S0104-40602015000200067\&lng=pt\&n $\underline{\mathrm{rm}=\mathrm{iso} \& \ln \mathrm{ln}=\mathrm{en}}$ https://doi.org/10.1590/0104-4060.41444

Veiga, M., \& Stoltz, T. (2014). O pensamento de Rudolf Steiner no debate científico [The Thought of Rudolf Steiner in the Scientific Debate]. Campinas: Alínea.

Vieira, T. C., \& Castanho, M. E. (2008). A importância da arte na educação: Algumas reflexões [The Importance of Art in Education: Some Reflections]. Teoria e Prática da Educação, 11, 75-78.

Vygotsky, L. S. (2001). Psicologia da arte [Psychology of Art]. São Paulo: Martins Fontes. 
Vygotsky, L. S. (2009). Imaginação e criação na infância: Ensaios psicológicos-livro para professores [Imagination and Creation in Childhood: Psychological Essays-Book for Teachers]. São Paulo: Atica.

Vygotsky, L. S. (2010). Psicologia Pedagógica [Pedagogical Psychology]. São Paulo: Martins Fontes.

Submit or recommend next manuscript to SCIRP and we will provide best service for you:

Accepting pre-submission inquiries through Email, Facebook, LinkedIn, Twitter, etc.

A wide selection of journals (inclusive of 9 subjects, more than 200 journals)

Providing 24-hour high-quality service

User-friendly online submission system

Fair and swift peer-review system

Efficient typesetting and proofreading procedure

Display of the result of downloads and visits, as well as the number of cited articles

Maximum dissemination of your research work

Submit your manuscript at: http://papersubmission.scirp.org/

Or contact ce@scirp.org 